\title{
MONITORING ACCURACY AND CONTROL PROCESSES DURING PROBLEM SOLVING - AN OVERVIEW
}

\author{
Loredana MIHALCA ${ }^{\mathrm{a} *}$ \\ a) Babeș-Bolyai University, Faculty of Economics and Business Administration, \\ Cluj-Napoca, Romania
}

Please cite this article as:

Article History:

Mihalca, L., 2018. Monitoring accuracy and control

Received: 9 October 2018 processes during problem solving - An overview. Accepted: 15 November 2018 Review of Economic Studies and Research Virgil Madgearu, 11(2), pp.73-90.

doi: 10.24193/RVM.2018.11.27.

Abstract: Being able to accurately monitor one's own performance (i.e., keep track of learning process) is crucial for self-regulation, especially when learning from problem-solving tasks. Effective monitoring depends on students' ability to use cues that are predictive for performance. These cues may include, for example, domain prior knowledge, which have been shown to have a positive relationship with monitoring accuracy. Inaccurate monitoring can lead to ineffective control, which may be harmful to the learning outcomes. As such, both accurate monitoring and adequate control seem to be crucial for effective self-regulation when learning from problem-solving tasks. Although problem-solving tasks play an important role in education, only very few studies have investigated the link between monitoring accuracy, control decisions, and performance in the context of problem solving. This paper reviews and discusses the findings of the existing research on monitoring and control in problem-solving tasks, while exploring the limitations of these studies as well as areas for future research.

Key words: metacognitive judgments; self-regulation; task selection; prior knowledge

JEL Classification: I21O

(c) 2018 Alma Mater Publishing House. All rights reserved.

* Corresponding author. E-mail address: loredana.mihalca@econ.ubbcluj.ro. 
Review of Economic Studies and Research Virgil Madgearu, 2018, 11(2)

\section{References:}

1. Ackerman, R. and Thompson, V., 2015. Meta-reasoning: What can we learn from meta-memory. In A. Feeney and V. Thompson, eds. 2015. Reasoning as Memory. Hove: Psychology Press. pp. 164-178.

2. Alexander, P.A., 2013. Calibration: What is it and why it matters? An introduction to the special issue on calibrating calibration. Learning and Instruction, 24, pp. 1-3.

3. Anderson, J.R. and Lebiere, C., 1998. Knowledge representation. The atomic components of thought. Lawrence Erlbaum Associates, Inc., Publishers.

4. Ariel, R., Dunlosky, J. and Bailey, H., 2009. Agenda-based regulation of study-time allocation: When agendas override itembased monitoring. Journal of Experimental Psychology: General, 138, pp.432-47.

5. Atkinson, R.K., 2002. Optimizing learning from examples using animated pedagogical agents. Journal of Educational Psychology, 94(2), pp.416-27.

6. Baars, M., Van Gog, T., De Bruin, A. and Paas, F., 2014a. Effects of problem solving after worked example study on primary school children's monitoring accuracy. Applied Cognitive Psychology, 28(3), pp.382-91.

7. Baars, M., Van Gog, T., De Bruin, A. and Paas, F., 2017a. Effects of problem solving after worked example study on secondary school children's monitoring accuracy. Educational Psychology, 37(7), pp.810-34.

8. Baars, M., Vink, S., Van Gog, T., De Bruin, A. and Paas, F., 2014b. Effects of training self-assessment and using assessment standards on retrospective and prospective monitoring of problem solving. Learning and Instruction, 33, pp.92-107.

9. Baars, M., Visser, S., Van Gog, T., De Bruin, A. and Paas, F., 2013. Completion of partially worked-out examples as a generation strategy for improving monitoring accuracy. Contemporary Educational Psychology, 38, pp.395-406.

10. Baars, M., Wijnia, L., and Paas, F., 2017b. The association between motivation, affect, and self-regulated learning when solving problems. Frontiers in Psychology, 8, pp.1346-58. 
Minalca, Monitoring Accuracy and Control Processes...

11. Bjork, R. A., Dunlosky, J. and Kornell, N., 2013. Self-regulated learning: Beliefs, techniques, and illusions. Annual Review of Psychology, 64, pp.417-44.

12. De Bruin, A. and Van Gog, T., 2012. Improving self-monitoring and self-regulation of learning: From cognitive psychology to the classroom. Learning and Instruction, 22, pp.245-98.

13. Dinsmore, D.L. and Parkinson, M.M., 2013. What are confidence judgments made of? Students' explanations for their confidence ratings and what that means for calibration. Learning and Instruction, 24, pp.4-14.

14. Dunlosky, J. and Lipko, A.R., 2007. Metacomprehension: A brief history and how to improve its accuracy. Current Directions in Psychological Science, 16, pp.228-32.

15. Dunlosky, J. and Metcalfe, J., 2009. Metacognition. Thousand Oaks, CA: Sage.

16. Dunlosky, J. and Rawson, K.A., 2012. Overconfidence produces underachievement: Inaccurate self-evaluations undermine students' learning and retention. Learning and Instruction, 22(4), pp.271-80.

17. Dunlosky, J. and Thiede, K.W., 2013. Four cornerstones of calibration research: Why understanding students' judgments can improve their achievement. Learning and Instruction, 24, pp.58-61.

18. Glenberg, A.M. and Epstein, W., 1987. Inexpert calibration of comprehension. Memory \& Cognition, 15, pp.84-93.

19. Griffin, T.D., Jee, B.D. and Wiley, J., 2009. The effects of domain knowledge on metacomprehension accuracy. Memory \& Cognition, 37(7), pp.1001-13.

20. Hadwin, A.F. and Webster, E.A., 2013. Calibration in goal setting: Examining the nature of judgments of confidence. Learning and Instruction, 24, pp.37-47.

21. Huff, J.D. and Nietfeld, J.L., 2009. Using strategy instruction and confidence judgments to improve metacognitive monitoring. Metacognition and Learning, 4(2), pp.161-76.

22. Jonassen, D.H., 1997. Instructional design models for well-structured and ill-structured problem-solving learning outcomes. Educational Technology Research and Development, 45(1), pp.65-94.

23. Kicken, W., Brand-Gruwel, S. and Van Merriënboer, J.J., 2008. Scaffolding advice on task selection: a safe path toward self-directed 
Review of Economic Studies and Research Virgil Madgearu, 2018, 11(2)

learning in on-demand education. Journal of Vocational Education and Training, 6o(3), pp.223-39.

24. Kimball, D.R., Smith, T.A. and Muntean, W.J., 2012. Does delaying judgments of learning really improve the efficacy of study decisions? Not so much. Journal of Experimental Psychology: Learning, Memory, and Cognition, 38, pp.923-54.

25. Koriat, A., 1993. How do we know that we know? The accessibility model of the feeling of knowing. Psychological Review, 100, pp.609-39.

26. Koriat, A., 1997. Monitoring one's own knowledge during study: a cue-utilization approach to judgments of learning. Journal of Experimental Psychology: General, 126, pp.349-70.

27. Koriat, A., 2012. The relationships between monitoring, regulation and performance. Learning and Instruction, 22(4), pp.296-98.

28. Kostons, D., Van Gog, T. and Paas, F., 2010. Self-assessment and task selection in learner-controlled instruction: Differences between effective and ineffective learners. Computers \& Education, 54, pp.932-40.

29. Kostons, D., Van Gog, T. and Paas, F., 2012. Training self-assessment and task-selection skills: A cognitive approach to improving selfregulated learning. Learning and Instruction, 22, pp.121-32.

30. Leonesio, R.J. and Nelson, T.O., 1990. Do different metamemory judgments tap the same underlying aspects of memory? Journal of Experimental Psychology: Learning, Memory, and Cognition, 16(3), pp.464-70.

31. Meeter, M. and Nelson, T.O., 2003. Multiple study trials and judgments of learning. Acta Psychologica, 113, pp.123-32.

32. Metcalfe, J. and Finn, B., 2008. Evidence that judgments of learning are causally related to study choice. Psychonomic Bulletin \& Review, 15(1), pp.174-79.

33. Metcalfe, J., Schwartz, B.L. and Joaquim, S.G., 1993. The cuefamiliarity heuristic in metacognition. Journal of Experimental Psychology: Learning, Memory, and Cognition, 19, pp.851-61.

34. Mihalca, L., Mengelkamp, C. and Schnotz, W., 2017. Accuracy of metacognitive judgments as a moderator of learner control effectiveness in problem-solving tasks. Metacognition and Learning, 12, pp.357-79.

35. Mihalca, L., Mengelkamp, C., Schnotz, W. and Paas, F., 2015. Completion problems can reduce the illusions of understanding in a computer-based learning environment on genetics. Contemporary Educational Psychology, 41, pp.157-71. 
Mihalca, Monitoring Accuracy and Control Processes...

36. Mihalca, L. and Mengelkamp, C. (submitted). Effects of induced levels of prior knowledge on monitoring accuracy and performance when learning from self-regulated problem solving.

37. Nelson, T.O., 1996. Consciousness and metacognition. American Psychologist, 51, pp.102-16.

38. Nelson, T.O. and Dunlosky, J., 1991. When people's judgments of learning (JOLs) are extremely accurate at predicting subsequent recall: The "delayed-JOL effect". Psychological Science, 2(4), pp.267-70.

39. Nelson, T.O. and Leonesio, R.J., 1988. Allocation of self-paced study time and the „labor-invain effect.“ Journal of Experimental Psychology: Learning, Memory, and Cognition,14(4), pp.676-86.

40. Nelson, T.O. and Narens, L., 1990. Metamemory: A theoretical framework and new findings. In G.H. Bower, ed. 1990. The psychology of learning and motivation. New York: Academic Press. pp. 125-41.

41. Nelson, T.O. and Narens, L., 1994. Why investigate metacognition? In J. Metcalfe, \& A.P. Shimamura, eds. 1994. Metacognition: Knowing about knowing. Cambridge, MA: MIT Press. pp. 1-25.

42. Nietfeld, J.L. and Schraw, G., 2002. The effect of knowledge and strategy training on monitoring accuracy. The Journal of Educational Research, 95, pp.131-42.

43. Pieger, E., Mengelkamp, C. and Bannert, M., 2016. Metacognitive judgments and disfluency- does disfluency lead to more accurate judgments, better control, and better performance? Learning and Instruction, 44, pp.31-40.

44. Renkl, A. and Atkinson, R.K., 2003. Structuring the transition from example study to problem solving in cognitive skill acquisition: A cognitive load perspective. Educational Psychologist, 38(1), pp.15-22.

45. Rhodes, M.G. and Tauber, S.K., 2011. The influence of delaying judgments of learning on metacognitive accuracy: A meta-analytic review. Psychological Bulletin, 137, pp. 131-148.

46. Schraw, G., 2009. A conceptual analysis of five measures of metacognitive monitoring. Metacognition and Learning, 4(1), pp.33-45.

47. Son, L.K. and Metcalfe, J., 2000. Metacognitive and control strategies in study-time allocation. Journal of Experimental Psychology: Learning, Memory, and Cognition, 26, pp.204-21. 
48. Sweller, J., 2003. Evolution of human cognitive architecture. In B. Ross, ed. 2003. The Psychology of Learning and Motivation. San Diego: Academic Press. pp.85-106.

49. Thiede, K.W., Anderson, M.C.M. and Therriault, D., 2003. Accuracy of metacognitive monitoring affects learning of texts. Journal of Educational Psychology, 95(1), pp.66-73.

50. Thiede, K.W., Griffin, T.D., Wiley, J. and Redford, J.S., 2009. Metacognitive monitoring during and after reading. In D.J. Hacker, J. Dunlosky and A.C. Graesser, eds. 2009. Handbook of metacognition in education. New York: Routledge, pp.85-106.

51. Townsend, C.L. and Heit, E., 2011. Judgments of learning and improvement. Memory \& Cognition, 39(2), pp.204-16.

52. Winne, P.H. and Hadwin, A.F., 1998. Studying as self-regulated learning. In D. J. Hacker, J. Dunlosky and A.C. Graesser, eds. 1998. Metacognition in educational theory and practice. Hillsdale: Erlbaum. pp. 277-304.

53. Yates, J.F., 1990. Judgment and decision making. Englewood Cliffs, NJ, USA: Prentice Hall, Inc. 